\title{
AGREEMENT ON THE MATTERS OF RELIGION CONCLUDED DURING THE ASSEMBLY OF TERRITORIAL ESTATES IN PERNAU (1552) IN CONTEXT OF THE DISPUTE OF RIGA (1549-1554)
}

\author{
MARGARITA NOVIKOVA \\ Mg. hist. \\ E-mail:margarita.novikova@inbox.Iv
}

\begin{abstract}
The article focuses on the history of the agreement text produced during the assembly of Livonian estates in Pernau in 1552, its background and connections to the dispute of Riga (1549-1554). Results indicate that the agreement was concluded between Livonian cathedral chapters and nobilities. The agreement concerning the religion was phrased under the influence of the representatives of the territorial estates of the archbishopric of Riga; its interpretation depends on the understanding of the extended "council phrase", because the cathedral chapter of Riga used it to achieve broader opportunities in their attempts to regain the secularized property.
\end{abstract}

Keywords: Reformation, Livonia, diets, dispute of Riga, assembly of territorial estates in Pernau in 1552, freedom of faith, cathedral chapter of Riga.

\section{INTRODUCTION}

The impact of the Reformation on the history of Livonia is well established in historiography. Two events are often mentioned in respect to the spread of Reformation across Livonia. The assembly of the ambassadors of the Livonian territorial estates in Pernau (present-day Pärnu in Estonia) in 1552 and the Livonian Diet in Wolmar (present-day Valmiera in Latvia) in 1554. These are thought to have univocally decided on a religious freedom for all of Livonia. Both sources are well known since the $18^{\text {th }}$ century. 
Both are important to the historiographical narrative, as they mark great advancement of the Reformation and underline the contrast that should have existed between the widespread new faith and the old ecclesiastical political system just before its dissolution during the Livonian War (15581583) (Arndt 1753, 217; Brachmann 1850, 197-198; Richter, A. v. 1857, 304-305; Müller 2014, 323-327; Arbusow, 1918, 820-822; although not: Pistohlkors 1994, 156-157). Interestingly, both of these events (the texts that inform us thereof and the contexts that surrounded their production), along with the religious situation in Livonia in the early 1550s have not been studied in detail yet, making it one of the recognized blind spots (see: Juhan Kreem (2014b, 183)). Additional research is motivated by the fact that newer studies of the religious situation in 1540s partially contradict the aforementioned narrative by demonstrating that religious reforms depended on the political situation rather than personal beliefs (Maasing 2019, 269-272; Kreem 2019, 458-462; Lange 2014, 146-156; Hartmann 2004, 276-277; Müller 2014, 298).

The aim of this paper is to analyse the agreement concerning the religion that was produced at the assembly of territorial estates in Pernau in 1552 (hereafter - agreement of 1552) within the contemporary political context, more precisely, in connection with the dispute of Riga. The paper reviews the circumstances of production, issuers and authors, determines the political context and pragmatic aspects of the way the agreement was phrased. The results are obtained through text analysis and comparative analysis of the agreement and related sources, historically-genetic synthesis of the way the relevant phrases were altered, and interpretation of the pragmatic meaning of the phrases and their change in context of the politics advanced by their possible authors. ${ }^{1}$

\section{THE AGREEMENT OF 1552: PREHISTORY, SOURCES AND AUTHORS}

In early 1552, as the negotiations with Tsar Ivan the Terrible (Иван IV Васильевич Грозный, years in office: 1533-1583) about a prolongation of peace treaty with Muscovy that had to end in September 1552, were not moving forward, the landlords, primarily Master of the Livonian Order Heinrich von Galen (years in office: 1551-1557) had raised a question of military tax in order to prepare for defense (Hartmann (1551-1557), No. 1556, No. 1556/1, 1554). Since the nobility of the lands of the Order proclaimed it to be a matter that concerned other territorial estates, the Master had to ask other Livonian landlords Archbishop of Riga Wilhelm von Brandenburg (years in office: 1530-1540 as coadjutor, 1540-1564), Bishop of 
Curonia and Administrator of Samland-Wiek Johannes von Münchhausen (years in office: 1540-1560 and 1542-1560), and Bishop of Dorpat Herman von Wesel (years in office: 1552-1560) to send representatives of their respective cathedral chapters, nobility and towns, whose privileges granted them freedom from taxes, to discuss the question together during a separate assembly (Hartmann (1551-1557), No. 1554, 1554/3, 1559). On 10 July 1552, the ambassadors of all territorial estates including those from the towns of Riga, Reval (present-day Tallinn in Estonia) and Dorpat (present-day Tartu in Estonia) convened in Pernau. The final agreement stated: everyone should stay by the same religion and pastoral care until the decision of a church council or a univocal agreement, the estates also refused to agree to a tax, or fund a school, instead they promised to participate in the defense of the land according to their traditional duties, decided to postpone an answer regarding the recruitment of mercenaries, proposed a draft of a regulatory ordinance (Polizeiordnung), agreed on the matter of runaway peasants and trade in towns (Hartmann (1551-1557), No. 1565, NNM, 7./8. Bd., 341-342). These decisions were presented to the landlords (Hartmann (1551-1557) No. 1565; Brevern 1842, 157-159) later that year. They themselves reviewed the questions during the following Livonian diet, which gathered in Wolmar only in January of 1554. As considered in the historiography, they approved the decision of the estates on the matters of religion (Richter, A. v. 1857, 304-305; Brachmann 1850, 197-198). It is not clear what motivated a discussion and a decision on the topic of religion in 1552 in the first place? Although the religious question was traditionally placed as the first in both agreement texts, in 1552 it appears to have been just an addition to the main problem of military tax; the surprised reaction of the Archbishop of Riga Wilhelm von Brandenburg also shows that this topic was not a part of the initial agenda (Hartmann (1551-1557) No. 1565). Although this and some other additional questions were probably discussed just because an opportunity for an assembly had occurred, this does not revoke the question about the motivation and the goals behind the discussions and the agreement on the matters of religion (hereafter - the agreement).

Historiography usually reviews both agreements (1552 and 1554) as connected and attributes them to the grade of the Lutheranisation of Livonia and the situation in the Holy Roman Empire, i.e., the Treaty of Passau (2 August 1552). For example, Wilhelm Brachmann saw the decision of 1552 as the expression of the common standpoint of Lutheranised estates that was made possible by the fact that they had convened separately from the landlords, which is to general and only serves to prove the known tendency for Lutheranisation rather than explain the agreement itself (Müller 2014, 322327; Richter 1857, 304-305; Brachmann 1850, 198; Arbusow 1918, 820-822). 
The treaty of Passau is mostly seen as the event that allowed the landlords to make the decision in 1554. It had ended the Prince's Revolt (Fürstenaufstand, 1552) - a war started by an alliance of imperial princes (one of whom was a brother of archbishop Wilhelm - Albert of Prussia (Albrecht von Preussen, years in office: 1510-1525 as the last Master of the Teutonic Order in Prussia, 1525-1568)), as a reaction to the emperor's politics, the most important part of it being the publication of the Augsburg Interim (1548) - a religious law that imposed certain, mostly unacceptable, religious norms on the Protestants. The history of the decision regarding the religion that was concluded in Passau, started in April 1552, after the factual victory of the princes, with the so-called Program script (Programmschrift) of their leader Maurice Prince Elector of Saxony (Moritz Kurfürst von Sachsen, years in offices: 1541-1547 as duke, 1547-1553 as Prince Elector). It demanded confessional inviolability and everlasting peace for the Protestant estates. This demand was partly fulfilled in the preliminary agreements (Passauer Abrede) met by the deputies of both opposing parties, they had agreed that the peace should last until a univocal agreement. Then in July during the negotiations with the emperor Charles $\mathrm{V}$ (Karl V, years in office: 1519-1556) himself this decision was partly affirmed as he only agreed to grant these freedoms until the next imperial diet (Drecol 2000, 10-57). The information about the prince's demands could have been publicly known since the spring, but to conclude whether in fact the Livonian agreement was inspired by the imperial public discourse surrounding the Prince's Revolt and the demands of the victorious side, one would have to know more about the scope of information that was available in Livonia before July 10. Wilhelm's of Brandenburg correspondence shows that he regularly received newspapers from the Holy Roman Empire and the position of the emperor was known in Livonia in May. It also attests that he was not supportive of the emperor (Hartmann (1551-1557) No. 1561), but upon receiving an invitation to the Council of Trent in October, his intentions were to behave as a complacent prince of the empire (Hartmann (1551-1557) No. 1565). The Order hesitated to react to the news about the complicated situation of the emperor in May of 1552. This indicates that even though the emperor suffered a defeat and the situation had changed in comparison to 1548-1549, at least the landlords were careful in their actions. Additionally, this was exactly what Albert of Prussia had advised his brother to do (Hartmann (1551-1557), No. 1565, 1554, 1558, 1559, 1526).

Thus, the events in the empire could have created favourable circumstances for the later decision of 1554, and might have inspired the decision made in 1552 (as hypothesised by Thomas Lange (2013, 174-175)), but the connection remains unclear. Even if the events in the empire had 
inspired the decision, this does not explain the goal behind the Livonian decision of 1552 - one would have to know whether the territorial estates just repeated the discourse in the empire or not, and why?

These questions are especially intriguing, because the Augsburg Interim that was cancelled by the Treaty of Passau (it was one of its goals) had been received with mixed reaction by the Livonian landlords and territorial estates in 1548 when it was first published. The towns were against it. A part of the Order was against it, as well. The Order in general was torn between the political need to refrain from sabotaging the relationship with the Holy Roman Emperor, simultaneously preserving good relationship with the Lutheran towns, a great deal of its brethren were Protestant and personally were opposed to it. The archbishop was personally torn between his wish and need to defend the Protestants, his ecclesiastical position, as well as the need to uphold the relationship with the emperor and to use the Interim for his political goals. Meanwhile, the reaction of the bishops, other cathedral chapters and nobilities is mostly unknown, for example, the bishop of Curonia and Samland-Wiek tried to introduce the Interim but failed, the cathedral chapter of Riga also expressed positive opinions about this imperial law (Kreem 2014a, 136-139, Müller 2014, 314-317). In 1552 the political situation in the empire might have provided an opportunity for the Master or the archbishop to solve both problems - to act in accordance with the emperor's politics and in friendship with Lutheran towns and also according to their beliefs, however, the same was not certain in respect to the cathedral chapters and possibly even the territorial nobilities, whose religious position at the time Kreem evaluates as ambivalent (Kreem 2019, 458).

The position of clerics and nobles proves to be especially relevant after a detailed review of the agreement document itself. The first and the only edition of the agreement of 1552 was published in 1794 from a contemporary transcript in a manuscript that belonged to an advisor of the archbishop and the standard-bearer of the archbishopric Heinrich von Tiesenhausen (approx. 1520-1600) and lacked the ending starting with the clause of corroboration (stating the means of authentication, i.e., that there are signatures and seals attached) of the context (the main middle part of the document's text) and including the whole eschatocol (the final closing part of the document's text containing the names of signing parties and the dates) (NNM, 7./8. Bd., 341-342). Thus, nothing caused doubt regarding the plausibility of the intitulation clause (the stating of the producers), where the agreement was attributed to all of the estates, towns and communities. Despite the fact that the ending was published in 1842 by Georg von Brevern (1842, 157-159) and showed that the representatives of the towns were not mentioned in the subscription clause (stating the signing parties), 
unfortunately, it did not find much recognition in the following historical works (Brevern 1842, 157-159; Arbusow 1918, 820-822). Of course, the lack of subscription on its own might not have compromised the traditional interpretation, after all, it was stated that the representatives were signing and sealing "gemeyne diesser Lande wegenn". ${ }^{2}$ However, the fact that the text contained articles, which disagreed with the general politics of the three major Livonian towns (returning of escaped peasants, etc.), as well as the strained relationship between the towns and the rest of the estates caused by those same disagreements suggests otherwise (NNM, 7/8 Bd., 341-342; Brevern 1842, 157-159; Niitemaa 1949, 287-289). Namely, the decision made during the assembly was an agreement between the ambassadors of the cathedral chapters and the territorial nobilities.

Thus, the religious peace of 1552 was put forward not only by confessionally heterogenous territorial nobilities, but also by the clerics who had favoured old faith and a part of whom had welcomed the Augsburg Interim in 1548-1549. On the contrary, the offer was insufficient to acquire the approval of the Lutheran towns.

Further new details about the production of the agreement, and especially the part concerning the matters of religion, can be gained from an undated document presented by archbishopric representatives during a "Landesverschreibung" - an "assembly of the land". It was published in the $5^{\text {th }}$ volume of Monumenta Livoniae antiqua and dated to approximately 1555, but needs to be attributed to the assembly of 1552 . This has been first proposed by Wilhelm Brachmann $(1850,198)$ and is supported by the fact that the proposition is thematically and structurally identical, but less developed than the final agreement of 1552, while many phrases, as well as all of the decisions are the same (including their rejection of a military tax), which is a sign of genetic connection (MLA, Bd. 5, No. 266; NNM, 7/8 Bd., 341-342; Richter, A. v. 1857, 304-305).

Although more sources are needed to draw a definitive picture, this proposition of the archbishopric's cathedral chapter and nobility, i.e., their ambassadors, was likely the textual source of the final agreement about the religion. Firstly, the protocol (introductory part of a document) of the final agreement states that the estates of the archbishopric had initiated the assembly. It might not be entirely true, as mentioned above the matter had arisen during the discussions in the Order and the question of religion might have been connected to the inner politics of the Order as well, although as we know, it was not a part of the initial agenda (NNM, 7/8 Bd., 341-342; Hartmann (1551-1557), No. 1565, see above). However, it might not be that important, whether the archbishopric estates initiated the discussion at all, because, secondly, the estates of the archbishopric (following the status of the archbishops themselves) aspired to and demanded to be considered 
the "eldest in the land", thus they were mentioned first in the documents and had the $1^{\text {st }}$ session in the negotiations, so this proposition could have been read first and they might have had more weight behind them during the actual discussions (NNM, 7/8 Bd., 341-342). This is important to note, because, thirdly, the part of their proposition that concerns the religion is almost identical to the final agreement and it can be concluded that the final agreement was not only phrased by the Livonian cathedral chapters and nobilities many of whom welcomed the Interim, but it happened under the influence of the cathedral chapter and the nobility of the archbishopric of Riga, of whom the chapter definitely had welcomed the Interim, and also was involved in a long lasting dispute over secularized ecclesiastical property in Riga, which made them not only theologically, but politically engaged with the religious question (Müller 2014, 308-322).

Hence, religious freedom until a decision by a church council or another univocal agreement was proposed by not at all confessionally indifferent representatives of the estates of the archbishopric who were institutionally interested to regain their secularized property in Riga.

\section{POLITICS OF THE CATHEDRAL CHAPTER OF RIGA DURING THE DISPUTE OVER SECULARIZED PROPERTY IN RIGA (1549-1551)}

The long-lasting dispute between the archbishop of Riga, the cathedral chapter of Riga and the town of Riga had started in 1526 as a consequence of Reformation. In the years to come it determined much of the archbishop's politics, the politics of the cathedral chapter as well as their relationship. During the negotiations, both sides, which had exactly the opposite demands, were always confronted with the need to surrender a part of them. The archbishop and the cathedral chapter had to compromise between the need to regain the property and income and to restore the old ecclesiastical order and power relations in the town. For example, in 1542 in the Agreement of Lemsal (present-day Limbaži in Latvia) the archbishop had to agree to sacrifice his ecclesiastical jurisdiction until a decision by a general or national church council in order to receive a promise that the town would return under archbishop's half-rule. The importance of the dispute has been reviewed in depth (see, for example: Müller 2014, 251-166, 308-322; Lange 2013, 151-157, 164-166), only the last episodes in 1549-1554 will be analysed for the purpose of this article.

The dispute had been renewed in 1549. The Archbishop Wilhelm von Brandenburg (and his advisors) could turn around Emperor's accusations of having supported the Union of Schmalkalden which he had received 
in November 1548 simultaneously with the order to enforce the Interim. He used this situation to renew the old dispute over the ecclesiastical property and jurisdiction in the town (Müller 2014, 312-317; Hartmann (1540-1551), No. 1459/2, No. 1468/3). This was possible, because Riga had been a member of the Union and was already facing retribution (Müller 2014, 315-317, Hartmann (1540-1551), No. 1468, No. 1468/3, No. 1468/4). During the summer of 1549 , the dispute was reviewed in the Aulic Council (Reichshofrat). (Müller 2014, 318-322; Hartmann (15401551), No. 1510). At the time the town was threatened by the emperor's order to introduce the Interim (1548) and possible fees (MLA Bd. 4., 47-59) for its support of the Union of Schmalkalden, thus, it was of no surprise that, contrary to the situation in the 1530s and 1540s, the town's ambassadors proposed a compromise - they were ready to bargain for Riga's religious freedom by returning a bulk of the property, but demanded from the archbishop to issue a written confirmation of their religious freedom. In general, the standpoints of both sides were still too antagonistic and the negotiations ultimately were unproductive (Müller 2014, 312-317; Hartmann (1540-1551), No. 1483). Afterwards, the emperor (i.e., the Aulic Council) appointed a commission of three arbitrary judges to review the dispute back in Livonia. These were: Master of the Order Johann von der Recke (years in office: 1542-1549 as coadjutor, 1549-1551), Bishop of Curonia (and Administrator of Samland-Wiek) and Bishop of Dorpat, Jodokus von der Recke (years in office: 1543-1551/1553). They had to solve the dispute or return it to the Aulic Council (Müller 2014, 318-322; Hartmann (1540-1551), No. 1510).

Local negotiations began on 9 February 1551 in Wolmar, following a Livonian diet, that was devoted to the peace treaty with Muscovy (Hartmann (1540-1551), No. $1506 / 1$, No. 1514, No. 1514/1). As before, the negotiations were unproductive. As the archbishop would later write to his brother, to avoid complete failure the arbitrators proposed an agreement project and the archbishop and the cathedral chapter decided to accept it (Müller 2014, 318-322; Hartmann (1540-1551), No. 1517). Its text was largely based on previously mentioned compromise propositions, the town was granted freedom to further use the cathedral for Lutheran sermons (Compare Hartmann (1540-1551), No. $1483 / 1$ and No. $1483 / 2$ to No. 1517/2). However, the text also briefly touched upon the subject of religious reform and church council. This part of the text warrants more attention, as its phrasing differed from the previous agreements concluded during the Livonian diets, as well as agreements regarding the dispute of Riga (in the 1540s). Previously, a demand for any or part of the change to be postponed until the free general or national church council had been a part of every agreement project - this phrase became a norm in Livonia, 
as it had happened in the empire - it allowed to postpone the decision and to move forward with other negotiations. Furthermore, in Livonia this proved to be especially useful for town's politics (Kreem 2014b, 188, 263; MLA, Bd. 5, No. 257). However, in this agreement project, the authors rephrased the sentence by adding a proposition that the final decision on the religious reform could not only be postponed until a decision by a free general or a national (imperial) church council, but also until a univocal decision made by the local landlords, estates and towns to accept and introduce a change in religion: "[...] Dajegen kan vnd will der herr Ertzbischof vndd Capittel geduld vnd leiden, die Jtzige angenhomene Religion *sampt den Cristlichen Ceremonien*3 Jn der Thumb Kirchen Zu pflegenn, So lang ein frei Christlich generall oder National Concilium, daruber, oder aber semptliche gemeine herrn Stande vnnd stedte der lande zu liefland Jm der Religion Enderung *dem Wordt gottes nicht zu wider* vornhemen vnd bewilligen." ${ }^{4}$ Moreover, the ambassadors of Riga were requested to promise their approval in advance in a reversal document (Regest - Hartmann (1540-1551), No. 1517/2, original GStA PK, XX HA, HBA D, No. 1517, Bl. 9v). Hence the decision about the reform, as well as the freedom granted to the towns would not just be postponed until a decision by a free general church council (i.e., the Lutherans could decide to accept it as such), but also until a local decision. Although other causes might have determined such alterations, it is important to note that they were beneficial for the "old faith" and the cathedral chapter and precarious for the Lutheran town, because a local decision was more probable and would more likely benefit the landlords.

An attempt to extend the council phrase was unsuccessful - it was unacceptable to Riga. After Johann von der Recke died in May of 1551, Riga negotiated a new guarantee of religious freedom in the town from his successor Heinrich von Galen, who had agreed to confirm all the privileges that had been granted by his predecessors and demonstrated his benevolence by attending a Lutheran sermon during the following ritual introduction into the town on 26 September. The town council, however, was expected to fulfil its part of the bargain (MLA, Bd. 4, 54; Hartmann (1551-1557), No. 1536, 1540/1). In December of 1551, an intermediary agreement was concluded on the basis of the aforementioned compromise propositions the cathedral chapter and the archbishop regained important parts of their previous possessions, the town - its freedom of religion until a free general church council. The decision was to be sent to the Aulic Council. The ensuing questions had to be discussed during court sessions led by the lords of the town - the Master of the Order and the Archbishop of Riga, the dispute remained partially unresolved (Müller 2014, 320-321; Hartmann (1551-1557), No. 1542). 
For the purpose of this article it is most important to note that the cathedral chapter continued to attempt and use an extended variant of the phrase. Another court session took place in September 1554 - at the end of these negotiations, the chapter tried to introduce a phrase similar to the one used in 1551 into the text of the new agreement. Rigans wished to postpone any further sessions until the church council. The disagreement could not be overcome and was so important that this caused a complete failure of otherwise promising negotiations; the dispute was to be sent to the Imperial Chamber Court (Reichskammergericht). As an Elder of the Great Guild of Riga, Reinhold Germann explained it the Book of Elders: "[...] de sullden stan tho Eyneme kristlycken ghene ralle [General - C. N.] Conssyllyum. Dar hebben de kappyttells heren samtt alle Ereme anhanghe nychtt an wyllen, sunder ydt sullde stan tho Eynneme Eynhellyghen ffryuyllyghen wor ghellykynghe [Vergleich - C. N.]"5 (MLA, Bd. 4, 87). His own note in a draft is more precise, it shows that the whole controversy started after the town that had agreed to a compromise, had asked that no further sessions would be held until the church council (LNA-LVVA, 214-6-100, 140-141). Hence, trying to introduce a wider meaning into the agreement or postponing the dispute until a session in the Imperial Chamber Court was more acceptable than settling with a compromise, but simultaneously agreeing to postpone any new sessions (and possible gains) until a (possibly indefinite) decision of a church council.

Thus, the ambitions of the cathedral chapter had not decreased since the 1530s, it tried to regain its possessions and authority completely (with the support of the ambassadors of the nobility). However, the methods changed, and the canons were ready to accept the religious freedom in the town as an intermediary situation. During the dispute the chapter repeatedly tried to phrase the agreement in a way that ensured the possibility of further negotiations and a local decision. The town's representatives were aware of this risk, refused to accept it and attempted to omit any further negotiations. The results of the court session in December of 1551 point to the fact that the cathedral chapter did not achieve its goals and was interested in further negotiations.

\section{THE MEANING OF THE AGREEMENT OF 1552 IN THE CONTEXT OF THE DISPUTE OF RIGA}

Aforementioned episodes from the history of the dispute and the attention that was given to seemingly minor changes in the phrasing of these agreements, finally turn the researcher's attention back to the assembly of 1552, as both the proposition of the archbishopric estates and the final 
agreement contained extended variants of the phrase about the church council. The proposition of the archbishopric estates repeats the agreement project of February 1551, but the final agreement contains the same phrase that would later be employed by the cathedral chapter in September of 1554. In 1551, the text stated that "oder aber semptliche gemeine herrn Stande vnnd stedte der lande zu liefland Jm der Religion Enderung *dem Wordt gottes nicht zu wider*vornhemen vnd bewilligen" (GStA PK, XX HA, HBA D, No. 1517, Bl. 9v). The proposition of 1552 stated that "[...] so viel die religion vnd gotlichs wordt belanget, sich diesser lande bewilligung nach (das ein Jder her, Standt vnd Stadt, bis vf ein frei christlich Concilium vnd einhellige bewilligung vnturbirt vnd vnangefochten gelassen werden soll) gemes halten [...]"7 (MLA, Bd. 5, No. 266; Richter, A. v. 1857, 304-305). The final agreement of 1552 was different: "[...] so viell die Religion vnd gottiges Worth belanget, das ein jeder hohes vnd niedrigen Standes, jn vnd bej demselbigen, vermuge affgerichteter Recesse, biß auff ein algemein cristlich Generall Concilium oder einhellige Vergleichung vnangefochten vnd vnturbirett gelaßen werden ßoll"8 (NNM, 7/8 Bd., 341-342). Lastly, in September 1554, the text stated that "[...] ydt sullde stan tho Eynneme Eynhellyghen ffryuyllyghen wor ghellykynghe" (MLA, Bd. 4, 87). Thus, during the production of the final agreement in 1552, the phrase was used and changed, probably, with the same goal that determined its use in 1554.

The fact that both extended variants of the phrase about the church council that were used in 1551 and 1554 were perceived as synonymousby the involved contemporaries (in spite of alterations) is supported by a statement that Rigan ambassadors made to the representatives of Reval and Dorpat during another assembly in February 1555. They explained, to anticipate any "ill-intentioned gossip", especially addressing those who had not been present during the court session in Wolmar in 1551, that the failure of the session in September of 1554 was caused by the fact that then, as in 1551, the cathedral chapter had tried to insert an unacceptable phrase into the agreement: "[...] das etliche art[ikel] $d$ [er] Religio[n] anhengig bis zu einhellig[en] vergleichung der hern stende vnd stet diesser lande stehen solt."). ${ }^{10}$ Although other ambassadors did not show any special interest in this account (TLA, 230-1-Br 14, p. 491. r.-493. r.), this also demonstrates that the Rigans perceived the neutral appearance of the phrase and felt the need to explain the connection to previous events in order to prevent false accusations.

The reason for altering the variant of 1551 might have been the reaction it had caused. In 1551 the agreement was met with more or less sharp negative reactions and the extended "council phrase" was at the heart of this criticism. While the Town Council called the topic of reform irrelevant to the negotiations on the property and jurisdiction, and asked to exclude 
it entirely, the more radical author directly connected this extended phrase and the possibility of a local decision to the threat of Augsburg Interim being imposed on the towns against their will. A pamphlet by a known supporter of Protestant cause, Johannes Lohmüller (approx. 1483-1560) criticized the agreement and damned its authors and the archbishop calling them "papists" and "interimists" (Müller 2014, 318-322; Hartmann (15401551), No. 1517/3). An entry made by an Elder of the Great Guild Laurentz Zimmermann, in the Book of Elders of the Great Guild of Riga explicitly brings forward such suspicions - here he cites the passage of the agreement that caused the controversy before giving his explanation: "[...] dat de stadt solde En reüertzal [Reversal - C. N.] geüen, darin vorwilgen offt vor schriüen, so de hern düsser lande hir im lande Ene vor andringe Im lande indem tzarmonien vnde gades Densten worden anrichten (wente se heddent Inttrim angenamen), dat wi vns dar In der stadt ock wolden ghelick metick [gleichmässig C. N.] na holden."11 (MLA, Bd. 4, 57]). This entry was made at the end of 1551 (MLA, Bd. 4, 60) and probably was connected to the polemics started by Lohmüller, however it shows that the phrase was the cause (or a pretext) for concern, because it attempted to change a normative traditional "council phrase" that had allowed to leave the religious question in the competence of higher authority instead of a local one.

This reaction seems to be rather polemical in nature. The original phrasing appears to have been rather neutral; the text also did not specify what kind of decision would be made. Additionally, an insert on the margin in a draft sent by the archbishop to his brother, Duke of Prussia, suggests that the Reform was supposed to be in accordance with the Evangelium ("[...] Im der Religion Enderung *dem Wordt gottes nicht zu wider* vornhemen."), ${ }^{12}$ which would make the neutral phrase used in the text itself sound more acceptable to the Lutherans and less vague and threatening (Jörgensen 2014, 63; GStA PK, XX HA, HBA D, No. 1517, Bl. 9v), however, the town might not have received a document that contained these notes. While the analysis of the actual motives of the authors in 1551 exceeds the scope of this article, it is important to note that in 1551 the Augsburg Interim was still sufficiently present in the local discourse, it allowed to discredit the agreement in the town and associate strong negative connotations to the text. It was those connotations that the estates of the archbishopric must have tried to overcome in 1552 and 1554 to persuade the towns, i.e., primarily Riga, to join the final agreement, thereby agreeing that the freedom of religion and other changes were only granted until some kind of univocal decision, including a local one. It was those connotations and the actual meaning that could later be employed for the benefit of its authors, which motivated Riga to refuse.

Although in 1551, as in 1554, the phrase was used unsuccessfully, it is hard to judge whether it was the single cause behind the refusal of towns 
to join the agreement of 1552 . For example, in January 1554, when the extended phrase was no longer present in the text of the diet agreement, they still refused to join it due to other articles (see above, MLA, Bd. 4, 71-72). Until more sources are available, one can presume that here the extended phrase might have been only one of many causes for disagreement.

The way the text was rephrased warrants more attention, as it reveals how the authors used contemporary discourse (local and imperial) to obscure the meaning in order to obtain the towns' approval. The comparison of the four available sources where the phrase appears shows that it was at first reduced and then rephrased using a synonym that was more general and ambiguous in meaning. This was achieved because, the term "Vergleichung" (agreement) was a legal term often used in the imperial diets as a synonym of a council or any other agreement and proclaimed the end goal of the emperor's politics in the religious question (Jörgensen 2014, 211, 240-253). "Bewilligung" (approval), on the other hand, was frequently applied in the discourse of Livonian diets when referring to an approved decision (see, for example: NNM, 7/8 Bd., 341-342). Although both were synonyms, a "univocal agreement" would sound more like a reference to a general agreement in the empire and would be more acceptable, and an "approval" - more like a reference to a local decision which had negative connotations.

It has to be noted that both sentences used in the sources of the assembly in 1552 that express the agreement itself and contain this phrase, were rather general in meaning, although they stated that everyone should stay by the same religion, they did not attribute it exclusively to Lutherans, as was done in 1551 and would be done in January 1554, when the texts used the words "angenommenen Religion" ("assumed confession") (GStA PK, XX HA, HBA D, No. 1517, Bl. 9V; MLA, Bd. 5, No. 266). The pro-Lutheran appearance of the proposition and the final agreement of 1552 seems to have been created by the only explicitly Lutheran phrase in the $2^{\text {nd }}$ part of the agreement $\mathrm{t}^{13}$ which states that the people should hear the sermons: "zw dem allein selichmachenden Wordtt Gottes gehalten"14 (NNM, 7/8 Bd., 341-342) - Kreem notes, that the agreement only contains this Lutheran sounding slogans omits any detail (Kreem 2019, 460-463). However, when Archbishop of Riga Wilhelm von Brandenburg informed his brother that the assembly had made some additional decisions. He explained the fragment of interest in a way that did not suggest that the decision was explicitly pro-Lutheran. He wrote: "[...] dass es bey jetziger Religion bis zum gemeinennn generall Concil bleiben, vnd dass gotlich wardt wie Itzo Im schwanng [ = üblich, im Gebrauch], gepredigt vnd gelerett werden sollte."15 (GStA PK, XX HA, HBA D, No. 1565, Bl. 5v) Since he did not use the phrase "angenomene Religion", it is hard to tell whether he meant that the decision agreement was proLutheran. In this interpretation, the new agreement sounded like it did, in 
fact (as proclaimed in the text) just repeat the previous diet agreements of 1532, when the decision to postpone any changes until a free general church council and let everyone observe their customs was last included into the text of a diet agreement, but was meant for the "old faith". In reality, the agreement of 1552 was markedly more pro-Lutheran when compared to explicitly neutral and empire-oriented diet agreement of 1532 (ARIII, N. 304., S. 771-772; Richter, A. v. 1857, 304-305).

Thus, the agreement of 1552 was phrased rather ambiguously and generally, although it contained a Lutheran phrase and, in comparison to the previous diets, sounded more Lutheran. In context with the Interim, whether it was inspired by the Treaty of Passau or not, this return to the old diet agreements was meaningful by itself, as it proclaimed the confessional inviolability of the estates, albeit until a future decision. Lastly, although the Lutheran phrasing and meaning could serve the intentions of other involved parties, including those who supported the Protestants, the ambiguity actually benefitted the estates that were supportive of the "old faith", like the cathedral chapter of Riga.

\section{CONCLUSIONS}

In conclusion, although the assembly of 1552 had taken place when Livonia was informed about the complicated situation of the emperor and might have come in contact with the imperial discourse and the demands of there bellious princes, additional sources are needed to understand how and why the contemporary situation in the empire might have influenced Livonian politics in 1552 and the agreement of the assembly of the territorial estates, and how this was connected to the situation that was created earlier by the Augsburg Interim.

Although the agreement of Pernau could have been inspired by the events in the empire in April-June of 1552, there is a substantial evidence that the local political interests played a role in phrasing and use of the agreement. Generally, the agreement followed the structure and somewhat even the phrasing of the previous diets of 1532 and 1537, but it also contained an extended "council phrase" connected to the agreement project that was proposed in 1551 . Thus, although the text was phrased to mean pro-Lutheran religious peace, it actually contained ambivalent elements. This later characteristic promised to be beneficial for the politics of the cathedral chapter of Riga.

Thus, the agreement of the assembly of the ambassadors of Livonian territorial estates and towns in Pernau in July of 1552 that was reached without the acceptance of towns was a product of contemporary political 
situation and not just an expression of the Lutheranisation of Livonia and religious freedom; moreover, its phrasing allowed to obscure the traditional "council phrase" and could have paved the way for further local negotiations on the matters of religion.

\section{ABBREVIATIONS}

AR III - Akten und Rezesse der livländischen Ständetage, Bd. 3.

GStAPK - Geheimer Staatsarchiv Preussischer Kulturbesitz (Secret State Archives of Prussian Cultural Heritage)

LNA-LVVA - Latvijas Nacionālā arhīva Latvijas Valsts vēstures arhīvs (Latvian State Historical Archives of National Archives of Latvia)

MLA - Monumenta Livoniae antiquae

NNM - Neue Nordische Miscellanen

RA - Rahvusarhiiv (National Archives of Estonia)

TLA - Tallinna linnaarhiiv

\section{LIST OF SOURCES AND LITERATURE} UNPUBLISHED SOURCES

Agreement project, [German] proposed in February 1551. Secret State Archives of Prussian Cultural Heritage (Geheimer Staatsarchiv Preussischer Kulturbesitz, hereinafter: GStA PK), XX HA, HBA D, No. 1517, p. 8.v-14.r.

Letter of Wilhelm von Brandenburg [German], 03.10.1552. - GStA PK, XX HA, HBA D, No. 1565, Bl. 1.v-8.r.

Draft of the entry by the Elder of the Great guild of Riga, Reinhold Germann, 1554, with a transcript by Johann Kristoph Brotze - Latvian State Historical Archives of National Archives of Latvia (Latvijas Nacionālā arhīva Latvijas Valsts vēstures arhīvs, hereinafter: LNA-LVVA), 214-6-100, p. 140-141.

Account of the negotiations between the ambassadors of Riga, Dorpat and Reval during an assembly in January 1555 - Tallin City Archives (Tallinna linnaarhiiv, hereinafter: TLA), 230-1-Br 14, p. 491. $\mathrm{r}-493 . \mathrm{r}$.

\section{PUBLISHED SOURCES}

Arbusow, L., Stavenhagen, O. (Hgs.), 1910. Akten und Rezesse der livländischen Ständetage, Bd. 3. Riga: J. Deubner. $1000 \mathrm{~S}$.

Brevern, G. von 1842. Schluss des Pernauschen Resesses vom Jahre 1552. Gesellschaft für Geschichte und Alterthumskunde der russischen Ostsee-Provinzen (Hg.). Mitteilungen aus dem Gebiete der Geschichte Liv-, Est- und Kurlands. Bd. 2. Riga: Nicolai Kymmel's Buchhandlung, 157-159.

Hartmann, S. (Bearb.), 2002. Herzog Albrecht von Preußen und Livland (1540-1551). Regesten aus dem herzöglichen Briefarchiv und den Ostpreußischen Folianten. (Kloosterhuis, J. und Heckman, D. (Hg.) Veröffentlichungen aus den Archiven Preussischer Kulturbesitz, Bd. 57) Köln: Böhlau. (hereinafter: Hartmann (1540-1551))

Hartmann, S. (Bearb.), 2005. Herzog Albrecht von Preußen und Livland (1551-1557). Regesten aus dem herzöglichen Briefarchiv und den Ostpreußischen Folianten. (Kloosterhuis, J. und Heckman, D. (Hg.) Veröffentlichungen aus den Archiven 
Preussischer Kulturbesitz, Bd. 57) Köln: Böhlau. (hereinafter: Hartmann (1551-1557))

Hupel, A. W. (Hgs.), 1794. Neue Nordische Miscellanen: Siebentes un Achtes Stück. Riga: Hartknoch, J. F.

Napiersky, C. E. (Hgs.), 1844. Monumenta Livoniae antiquae: Sammlung von Chroniken, Berichten, Urkunden und anderen schriftlichen Denkmalen und Aufsätzen, welche zur Erläuterung der Geschichte Liv-, Ehst- und Kurland's dienen. 4. Bd. Riga, Leipzig: Eduard Frantzen's Verlags-Comptoir.

Napiersky, C. E. (Hgs.), 1847. Monumenta Livoniae antiquae: Sammlung von Chroniken, Berichten, Urkunden und anderen schriftlichen Denkmalen und Aufsätzen, welche zur Erläuterung der Geschichte Liv-, Ehst- und Kurland's dienen. 5. Bd. Riga, Leipzig: Eduard Frantzen's Verlags-Comptoir.

\section{LITERATURE}

Arbusow, L., jun., 1921. Die Einführung der Reformation in Liv-, Est- und Kurland. (Verein für Reformationsgeschichte (Hg.). Forschungen zur Reformationsgeschichte. Bd. 3) Halle: R. Haupt.

Arndt, J. G. (Hgs.), 1753. Der Liefländischen Chronik Andrer Theil: Von Liefland unter seinen Herren Meistern, welche die alte Geschichte des Ordens und der benachbarten Völker erleutert: Sowol mit Zuziehung der gedruckten und ungedruckten Schriftsteller als fürnemlich aus einer zalreichen Menge alter Documente im Original, beglaubten Copeien und andern Abschriften zusammen getragen [..] Halle: Gebauer.

Brachmann, W., 1850. Die Reformation in Livland. Ein Beitrag zur Geschichte Livlands sowohl als der Reformation. Gesellschaft für Geschichte und Alterthumskunde der russischen Ostsee-Provinzen (Hg.). Mitteilungen aus dem Gebiete der Geschichte Liv-, Est- und Kurlands. Bd. 5. Riga: Nicolai Kymmel's Buchhandlung, S. 1-266.

Drecoll, V. H. 2000. Der Passauer Vertrag (1552). Einleitung und Edition. (Markschies, Ch. et al. (Hgs.) Arbeiten zur Kirchengeschichte. Bd. 79). Berlin: Walter de Gruyter.

Jörgensen, B., 2014. Konfessionelle Selbst- und Fremdbezeichnungen: Zur Terminologie der Religionsparteien im 16. Jahrhundert (Colloquia Augustana). Oldenbourg: De Gruyter.

Hartmann, S., 2004. Neue Quellen zur livländischen Koadjutorfehde 1555/6. Jähnig B. et al. (Hgs.). Aus der Geschichte Alt-Livlands: Festschrift für Heinz von zur Mühlen zum 90. Geburtstag. Münster: Lit, S. 275-306.

Kreem, J., 2014a. Das Augsburger Interim in Livland. Evangelische und Altgläubige in den baltischen Landen in der Mitte des 16. Jahrhunderts. Braun, K.-H. et al. Hgs. Historisches Jahrbuch, Jhg. 134. Freiburg: Alber, S. 121-141.

Kreem, J., 2014b. Die Religionsfrage auf den livländischen Ständeversammlungen 1522-1558. Mentzel-Reuters, A., Neitmann, K., Hgs. Preussen und Livland im Zeichen der Reformation. (Tagungsberichte der Historischen Komission für Ost- und Westpreussischen Landesforschung, Bd. 28). Osnabrück: fibre Verlag, S. 183-208.

Kreem, J., 2019. Die Reformationszeit. Brüggemann, K. et al. (Hgs.). Das Baltikum. Geschichte einer europäischen Region. Bd. 1. Von der Vor- und Frühgeschichte bis zum Ende des Mittelalters. Stuttgart: Hiersemann Verlag, S. 632-462.

Lange, T., 2014. Zwischen Reformation und Untergang Alt-Livlands: der Rigaer Erzbischof Wilhelm von Brandenburg im Beziehungsgeflecht der livländischen Konföderation und ihrer Nachbarländer, 2 T. Hamburg: Verlag Dr. Kovač.

Massing, M., 2019. Die Reformationsversuche im Erzbistum Riga in den 1540er und 1560er Jahren. Radosław Biskup et al. (Hgs.). Die Kirche im mittelalterlichen Livland 
(Ecclesia clerusque temporibus medii aevi. Vol. 5). Toruń: Widawnictwo Naukowe Uniwersytety Mikołaja Kopernika. S. 245-272.

Müller, U., 2014. Erzbischof Wilhelm von Riga und die Reformation in Livland 15351563. Mentzel-Reuters, A., Neitmann, K. (Hgs.). Preussen und Livland im Zeichen der Reformation. (Tagungsberichte der Historischen Komission für Ost- und Westpreussischen Landesforschung, Bd. 28). Osnabrück: fibre Verlag. S. 241-343.

Niitemaa, V., 1949. Die undeutsche Frage in der Politik der livländischen Städte im Mittelalter. Helsinki: Suomalainen Tiedeakatemia.

Novikova, M. Rīgas arhibiskapijas zemes kārtu politiskā pozīija laikā no Meklenburgas Kristofa ievēlēšanas par koadjutoru lìdz Brandenburgas Vilhelma nāvei (1556-1563). Magistra darbs. Rīga: Latvijas Universitāte, 2020.

Pistohlkors, G. v., 1994. Hg. Deutsche Geschichte im Osten Europas. Baltische Länder. Berlin: Siedler Verlag.

Richter, A. v., 1857. Geschichte der dem russischen Kaiserthum einverleibten deutschen Ostseeprovinzen bis zur Zeit ihrer Vereinigung mit demselben. Th. 1, Bd. 2. Die Zeiten der reingermanischen Entwicklung, 1158-1562. Riga: Kymmel.

\section{NOTES}

${ }^{1}$ Parts of this article are based on the results of author's master's thesis (Novikova 2020).

2 "[...] for the whole land."

$3 * *$ - mark a paratextual fragment.

4 "[..] in return the lord Archbishop and chapter are able to and are willing to tolerate an.d permit, that the current adopted religion *together with Christian ceremonies* would be observed in the cathedral church so long as a free Christian general or national church council or the common lords, estates and towns of the land of Livonia decide to introduce and agree upon a change in Religion *that will not be contrary to the God's word*."

5 "[...] here should be stated "till a Christian general church council". The canons of the cathedral chapter together with all of their supporters were unwilling to agree to this, rather [they demanded] it should state "till a univocal free agreement"."

${ }^{6}$ See No. 4.

7 "to act according to the accepted by the land [according to diet agreements] (that every lord, estate and town should be left undisturbed and unchallenged till a free Christian church council and a univocal approval) in matters that concern the religion and the word of God [sermon and pastoral care]".

8 and so much concerns the religion and the word of God [sermon and pastoral care], that everyone, of high or low class, in and by the same should be left undisturbed and unchallenged till a free Christian church council and a univocal agreement according to the concluded diet agreements.

${ }^{9}$ See No. 5 .

10 "[...] that [the discussion of] some articles concerning the religion should be postponed till a univocal agreement of lords, estates and towns of the land".

11 "[...] that the towns must give a reversal document, wherein it will approve and promise, that it would agree and act accordingly, if the lords of this land would decide to introduce a change in church ceremonies and service (as if they have accepted the Interim) here in this land."

${ }^{12}$ See No. 4. 
${ }^{13}$ For the analysis and systematics of the Livonian agreements on the matters of religion, see Kreem 2014a.

${ }^{14}$ The second part of the agreement: "[...] und so viel Mangel vnd Gebrehcen der vorfallenen Kirchen, Gotesheusern, das dieselbigen hinfurth mith gotsforchtigen frommern Pfarhern vnd Dienern verßorgett vnd vorsehen werden mochten, vnd das arme Paurßvolck, so woll der Deutsche, von en groben Jrthummen, Zeuberej vnd dergleichen Gotslesterung, welche billick bej dem hogsten zw straffen, abgeleiteth, vnd zw dem allein selichmachenden Wordtt Gottes gehalten werden mochten vnd das ein jeder gesitliches vnd weltliches Standes, auch die Ritterschaft vnd Stette, ein jeder beßonder, bej ßeiner hohen Ubrigkeitt mith vleiße vorschaffe, vnd zu uorbieten haben soll, das jn deme wie es vor dem almechtigen zuuorantworten ßein will, nottwendigk Auffsehens vnd Vorßorge geschehe." Translation: "and concerning the lacking and defects of ruinous churches, temples, that these hereafter should be provided and equipped with Godly and devout pastors and servants, and the poor peasants, as well as the Germans, would be diverted from mistakes, witchcraft and similar blasphemy, which should be strictly punished, and kept under the saving word of God. And that everyone of clerical or secular status, including the nobility and towns, everyone by himself, would diligently ask and propose their lords that this matter should receive the necessary attention and care in a way that they will be able to be accountable for in front of the almighty."

15 "[...] that it should be left by the current religion and the sermons should be preached and learned as is customary until a general church council." 


\title{
PĒRNAVAS 1552. GADA KĀRTU SAPULCES RECESA LËMUMS RELIG̣IJAS JAUTĀJUMĀ RĪGAS ARHIBĪSKAPIJAS KĀRTU POLITIKAS KONTEKSTĀ
}

\author{
MARGARITA NOVIKOVA \\ Mg. hist. \\ E-pasts: margarita.novikova@inbox.Iv
}

\begin{abstract}
ANOTĀCIJA
Raksts pievēršas mazpētītam Livonijas reformācijas vēstures posmam, aplūkojot 1552. gada Livonijas kārtu sapulces recesu, tā priekšvēsturi un saiknes ar Rīgas strīdu 1549.-1554. gadā. Izpētes rezultātā tiek secināts, ka recess tika noslēgts starp Livonijas domkapitulu un bruṇniecības pārstāvjiem; lēmums religíijas jautājumā formulēts Rīgas arhibīskapijas kārtu pārstāvju ietekmē, un tā interpretācijā ir svarīgs tā dēvētais koncila frāzes paplašinājums, jo ar tā palīdzību Rīgas domkapituls varēja turpināt savu iepriekš un vēlāk piekopto politiku un mēgināt izveidot sev plašāku rīcību telpu strīdā par sekularizētajiem baznīcas īpašumiem Rīgā.
\end{abstract}

Atslēgas vārdi: Reformācija, Livonija, Rīgas strīds, Pērnavas 1552. gada kārtu sapulce, ticības brīvība, Rīgas domkapituls.

\section{KOPSAVILKUMS}

Raksta mērḳis ir analizēt lēmumu attiecībā uz reliǵiju, kas tika pieñemts sapulces laikā, kontekstā ar laikmetīgo politisko situāciju vai, precīzāk, Rīgas arhibīskapijas kārtu politiku. Raksts pievēršas 1552. gada kārtu sapulces recesa radī̌anas apstākḷiem, izdevējiem un avotiem, nosaka formulētā lēmuma teksta politisko kontekstu un mērḳus. Rezultāti iegūti, izmantojot avotu kritiku, teksta analīzi un salīdzinošo analīzi, vēsturiski ǵenētisko metodi un interpretācijas metodi.

Izpētes rezultātā tiek secināts, ka recess tika noslēgts starp Livonijas domkapitulu un bruņniecības pārstāvjiem; lēmums reliğijas jautājumā formulēts Rīgas arhibīskapijas kārtu pārstāvju ietekmē un tā interpretācijas procesā ir svarīgs t. s. "koncila frāzes" paplašinājums, jo ar tā palīdzību 
Rīgas domkapituls varēja turpināt savu iepriekš un vēlāk piekopto politiku un mēgināt izveidot sev plašāku rīcību telpu strīdā par sekularizētajiem baznīcas ìpašumiem Rīgā. 